\title{
Ornamental Motifs of Haft Rang Tiles in The Architecture of Houses Constructed in Shiraz in the Pahlavi Era*
}

\author{
Dordaneh Mohammadi゙
}

\begin{abstract}
In the Pahlavi-constructed areas of Shiraz, there are a number of residential houses built with modern architectural design, but traditional techniques and designs have been used in their decoration. Haft rang tiles are among the most commonly used techniques in the architectural decoration of these houses. The use of this ornamentation as seen in both internal and external views of Shiraz houses in the Pahlavi era is an exquisite example of the combination of tradition and modernity in contemporary Iranian architecture; studying its dimensions can lead to a better understanding of Iranian architecture in the contemporary period. Accordingly, this paper explores decorative features and diversity of ornamental motifs of Haft rang tiles in the architecture of houses built in Shiraz in the Pahlavi Era using a descriptive-analytical methodology. The required data was collected through field and library research. To this end, the tile decorations of 20 houses within the urban area of Shiraz constructed during the Pahlavi Era were investigated and categorized by the researcher in terms of spatial, framing, design, and motif diversity. According to the findings of the study, the Haft rang tile frames in the analyzed houses displayed a wide diversity of shapes including rectangles, squares, deformed vertical rectangles, curved surfaces, vertical diagonal frames, window frames, composite geometric shapes, and crowns. The most commonly used patterns in the sample group ( 20 houses were studied) were Eslimi (arabesque) and Khatai patterns. Human figures are also depicted in the form of archeological or miniature patterns or simple human shapes. Eslimi and Khatai patterns, flowers and birds, and human figures have been sometimes realistically portrayed, and sometimes portrayed in abstract forms. The dominant background colors of the tile frames in the studied period are turquoise and azure.
\end{abstract}

\section{Keywords}

Architectural decorations $\bullet$ Tile $\bullet$ Haft rang $\bullet$ House architecture $\bullet$ Pahlavi era $\bullet$ Shiraz

\section{Pehlevi Dönemine Ait Şiraz Konut Evleri Mimarisindeki Haft rang Çini Desenlerinin İncelenmesi}

\section{Öz}

Şiraz'da Pehlevi dönemine ait tarihi bölgede birtakım konut evleri bulunmaktadır. Bu konutlar modern yapılar olmasına rağmen dekorasyonlarında geleneksel teknikler ve tasarımlar kullanılmıştır. Haft rang (yedi renk) çiniler, bu tür evlerde en sık kullanılan dekoratif tekniklerden biridir. Bu süslemelerin Pehlevi döneminde Şiraz evlerinin iç ve dış görünümlerinde kullanılması, çağdaş İran mimarisinde gelenek ve modernitenin birleşiminin yeni bir örneğidir. Bu örneklerin kapsamlı incelenmesi, çağdaş İran mimarisinin daha iyi anlaşılmasını sağlayabilir. Buna göre, bu makalede, Pehlevi döneminde Şiraz konut evlerinin mimarisindeki yedi renk çinilerin dekoratif özellikleri ve çeşitli motifleri, tanımlayıcı-analitik yöntemle incelenmiştir. Bu makalenin verileri alan araştırması ve kütüphane çalışmalarına dayanmaktadır.

* This article is adopted from M.A thesis "A Study on the Features of Painted Tile Embellishments in the Architecture of the Houses in Pahlavi Era in Shiraz", supervised by M. S. Mirzaabolghasemi (Ph.D.), A. A. Seyedi (Ph.D.), consulting Assistant Prof. Ashkan Rahmani, September 2017.

** Correspondence to: Dordaneh Mohammadi (Master of Art Research), International Branch, Shiraz University, Shiraz, Iran. E-mail: dordanemohamadi@gmail.com ORCID: 0000-0001-9798-3557

To cite this article: MOHAMMADI, Dordaneh, "Ornamental Motifs Of Haft Rang Tiles In The Architecture Of Houses Constructed In Shiraz In The Pahlavi Era", Art-Sanat, 12(July 2019), s. 291-318.

https://doi.org/10.26650/artsanat.2019.12.0017 
Bu amaçla Pehlevi dönemine ait Şiraz'ın kentsel alanı incelenirken, 20 evin yedi renk çini dekorasyonu, uzam, çerçeveleme, motif ve desen çeşitliliği açısından sınıflandırılarak incelenmiştir.

Bu çalışmanın bulgularına göre, Pehlevi döneminde Şiraz evlerinin yedi renk çinilerinin çerçevesinin çeşitliliği sekiz tipte görülmektedir: dikdörtgen, kare, birleşmiş geometrik şekiller, deforma olmuş dikey dikdörtgen, eğri yüzeyler, dikey çatallı, taç, pencere çerçeveleri. Incelenen örneklerde kullanılan motiflerin çoğu Rumî ve Hatayî motiflerdir. İnsan figürleri, antik çağ eserlerinde olduğu gibi, minyatür olarak veya basit bir şekilde tasvir edilmiştir. Rumîler ve Hatayîler, gül ve bülbüller, insan figürleri bazen gerçekçi ve bazen soyut çizilerek renklendirilmiştir. Bu dönemde yedi renk çinilerde baskın renk olarak turkuaz ve kobalt mavisinin tonları kullanılmıştır.

Anahtar Kelimeler

Mimari dekorasyon • Yedi renk • Çini • Konut mimarisi • Pehlevi dönemi • Şiraz

\section{$\underline{\text { Genisletilmis } \ddot{O}_{z \text { et }}}$}

Şiraz'da Pahlavi dönemine ait tarihi bölgede birtakım konut evleri bulunmaktadır. $\mathrm{Bu}$ konutlar modern mimariye uygun şekilde yapılmakla birlikte dekorasyonlarında geleneksel teknikler ve tasarımlar kullanılmıştır. Haft rang (yeni renkli) çini, bu tür evlerde en sık kullanılan dekoratif tekniklerden biridir. Bu süslemelerin Pahlavi döneminde Şiraz evlerinin iç ve dış görünümlerinde kullanılması, çağdaş İran mimarisinde gelenek ve modernitenin birleşiminin yeni bir örneğidir. Bu örneklerin kapsamlı incelenmesi, çağdaş İran mimarisinin daha iyi anlaşılmasını sağlayabilir. Buna göre, bu makalede, Pahlavi döneminde Şiraz konut evlerinin mimarisindeki yedi renk çinilerin dekoratif özellikleri ve çeşitli motifleri tanımlayıcı-analitik yöntemle incelenmiştir. Bu makalenin verileri alan araştırması ve kütüphane çalışmalarına dayanmaktadır.

$\mathrm{Bu}$ amaçla Pahlavi dönemine ait Şiraz'ın kentsel alanı incelenirken, 20 evin yedi renk çinilerin dekorasyonu, uzam, çerçeveleme, motif ve desen çeşitliliği açısından sinıflandırarak incelenmiştir.

$\mathrm{Bu}$ çalışmanın bulgularına göre, Pahlavi döneminde Şiraz evlerinin yedi renk çinilerin çerçevesinin çeşitliliği sekiz tipte görülmektedir: dikdörtgen, kare, birleşmiş geometrik şekiller, büyük medallion, eğri yüzeyler, dikey çatallı, taç, pencere çerçeveleri. İncelenen örneklerde kullanılan motiflerin çoğu rumî ve hatayî’dir.

Şiraz'da Pahlavi dönemindeki yedi renk çinilerin baskın motifleri; çiçek, gül ve bülbül, rumî ve hatayî, madalyon şeklinde bulunan bitkisel desen ve desenleri içerir ve bunlar yedi renk çinilerin çerçevesini ve ana tasarımını oluşturur. Gül, bülbül, çiçek ve bitki tasarımlarını içeren bir grup motif, doğal türlerine benzer bir şekilde çizilmiştir. Diğer bir grup ise rumî, hatayî ve madalyon formları gibi soyuttur. Madalyonların bazılarında istisna olarak çiçekler gerçekçi bir şekilde kullanılmıştır.

Yedi renk çinilerin çerçevesini süsleyen hayvan ve kuş figürleri iki tiptedir. Kelebekler, kuşlar ve hayvanlar avlanma sahnelerinde farklı türde kullanılmıştır. İnsan 
figürleri, antik çağı eserlerinde olduğu gibi, minyatürler veya basit bir şekilde tasvir edilmiştir.

Doğal manzara desenleri, evlerin iç görünümünde bir cennet parçası andırmak amacıyla tasarlanmıştır. Mevcut örneklerde iki tip manzara deseni karşımıza çıkar: Biri daire şeklinde vazolar üzerinde, diğeri ise evin içini dekore etmek için bir çerçeve şeklinde tasvir edilmiştir. Çalışılan örneklerde geometrik motifler olarak şemse şeklinde on ve onaltı köşeli ve dört köşeli yıldızlar görülmektedir. Bu tür motifler hemen hemen Pahlavi dönemi yedi renk çinilerin çerçevesininin yarısını kaplamaktadır.

Kaçar dönemindeki renk değişimlerinin izleri Pahlavi döneminde görülebilir. Shiraz yedi renk çinilerin diğer örneklerden ayıran, sıcak renklerin, renk çeşitlerinin, koyu ve parlak kontrastın, tamamlayıcı renk kontrastının ve renk uyumunun kullanılmasıdır. Bu dönemde, kenar boşluklarını veya madalyonları astarlamak ve bazı durumlarda yüzeyleri boyamak için siyah renk kullanılmıştır. Kaçar döneminde hakim olan yeşil renk, yedi renk çinilerin çerçevesindeki küçük ve dağınık yüzeylere dönüşmüştür. Sarı da benzer şekilde kullanılmıştır. Yukarıda belirtilen özelliklere ek olarak Şiraz yedi renk çinilerin rengi, İsfahan'ın renk özellikleri Pahlavi döneminde yedi renk çinilerine eklenirken, ana arka plan renkleri olarak yüksek seviyelerde mavi ve turkuaz renkler kullanılmıştır. Pek çok kırmızı çiçek çok fazla renk çeşitliliğine sahip çiçeklere dönüşmüştür. Bu dönemde, hatai çiçekleri birçok farklı renkte tasvir edilmiştir. Bu dönemin resim çalışmalarında ahenk, aydınlık ve karanlık kontrastlar da görülmektedir. Bu dönemde hayvan figürlerinin boyanması önceki dönemlere göre daha gerçekçidir.

Yedi renk çinilerin motifleri ve desenlerinin tasarımında, ikide biri, dörtte biri ve sekizde biri simetri olarak kullanılmıştır. Bu dönemde daha çok dörtte biri simetri motifler yaygındır. Pahlavi döneminde çift olan çini çerçevelerinin yansıması ve benzerlikleri görülmektedir. Az sayıda çalışılan numunede simetri olmayanlar da gözlenmiştir. 


\section{Introduction}

With the rise of the Pahlavi regime in 1925, various social and cultural developments occurred in Iran. The physical expansion of cities and consequently urban construction were based on western sciences and techniques, but in that era they tried to keep a nationalistic decorative approach. The construction of massive governmental and non-governmental buildings was one of the hallmarks of these developments, which first occurred in government offices, schools, and mosques, and then in houses which changed the architectural model of all of them. New construction materials and modern engineering replaced the traditional architectural knowledge, but nationalist tendencies and efforts to pay attention to Iranian history led to the use of traditional decorations in the interior and exterior of buildings.

Shiraz, as one of the major cities in the Pahlavi era, was no exception to these developments. In the Pahlavi-construct of Shiraz, there is a collection of houses that have been built with commonly used techniques and materials. Traditional decorations and patterns such as mirroring, plastering, muqarnas, brickwork, mosaic tiles, and Haft rang tiles have been used as decorations in these houses. The use of Haft rang tiles has been one of the most commonly used architectural decorative practices in these houses, which are often seen in the exterior and sometimes interior views of the buildings. Haft rang tile is made based on the principles of painting on the tile and uses mineral colors applied on the fired clay. Then after drying, the tiles are fired for a second time. This method started from the Timurid period with seven colors and has continued in the same way but with more colors until the Pahlavi era. The construction and use of this type of tile began in the Timurid period and peaked in the Safavid period, and continued in the Zand and Qajar. This type of tile has been used in the Pahlavi era in Shiraz with a look at the surviving samples from Zand and Qajar periods.

The early stages of modern architecture in Iran have an unbreakable link with Iranian decorations and ornaments, and the use of Haft rang tiles in decorating the interior and exterior views of the houses built in Shiraz in the Pahlavi era can be considered as one of the manifestations of this trend. Unfortunately, these houses destroyed over time without registration and historical valuation. This article addresses the decorative properties and diversity of motifs and patterns of Haft rang tile motifs in the architecture of houses constructed in the Pahlavi era in Shiraz. For this purpose, 20 houses in different districts were selected. These houses had 53 tile frames in exterior and interior views which formed the basis for this study. The required data collected through field and library. This study addresses the following questions:

1. What are the main features of Haft rang tiles in houses constructed in the Pahlavi era in Shiraz?

2. What are the motifs and patterns used in Haft rang tiles in houses constructed in the Pahlavi era in Shiraz? 


\section{Literature Review}

The book, Glazes, Tiles, and Pottery, provides a professional description of science and technology related to tiling ${ }^{1}$. Kayani, in An Introduction to the Art of Tiling in Iran, in addition to explaining the way different tiles and designs were created, points to advances in the use of motifs that imply the increasing skill of Iranian artists and the craftsmen. Then he, discusses tiling and its varieties including monochrome tiles, mosaic tiles, Haft rang tiles, golden-colored tiles, and tiles combined with bricks, pottery inscriptions, and tiles ${ }^{2}$. In another book by the same author, titled Decoration Related to the Islamic Architecture of Iran, various types of decorations of the Islamic period are discussed. In this book, the section on tiling provides explanations about the use of tiles as both decorative and reinforcing element and reviews the ancient history of this industry and art. It also discusses the evolution of the use of different colors in tiles and ends up in Haft rang tiles ${ }^{3}$. Another book, A Review of the Elements and Architecture of Iran addresses different types of architectural decorations used in Iran. In this book, decorations are considered one of the features of Iranian architecture before and after Islam and as an important element of constructions and their strength. ${ }^{4}$ In a 3 -volume book entitled Iranian Tile Work, Zomrashidi addressed a variety of tile work including Kofi-scripted tiling and different composite motifs and patterns made of checkered squares. The first volume discusses the Kofi-scripted knot and the evolution of this art. The second and third volumes deal with the use of Kofi-scripted lines for decorating vertical column heads, horizontal inscriptions, and many other cases in architecture. These books provide a professional account of Kofi-scripted tile work but contain little information on Haft rang tiles. ${ }^{5}$ Porter, in the book, Islamic Tiles, considers these tiles to be of cultural and artistic value in the Islamic world, and deals with artisans and tile making techniques in all Islamic lands. ${ }^{6}$ In his book, Girih Tiling Volume II, Maherolnaghsh describes the tile decorations in motif design and implementation in Iranian tile work during the Islamic period stating that tiles were first used for inscriptions. ${ }^{7}$ In another book (Tile and its Applications), the same author discusses the ways in which tiles are built and produced with an emphasis on mosaic tiles. ${ }^{8}$ Alawi, addresses tile making techniques and colors used by craftsmen and provides

1 A. Sharveh, M. Anoosafar, Glaze, Tile, and Pottery, Tehran 1995, pp. 15-25.

2 Muhammad Yousof Kayani, Introduction to Iranian art of Tiling, Tehran 1983, pp. 13-24.

3 Muhammad Yousof Kayani, Decorations Related to Iranian Architecture in the Islamic Period, Tehran 1997, pp. 129-130.

4 H. Yavari, S. Hakkakbashi, Elements and Decorations of Iranian Architecture, Tehran 2011, p. 31.

5 Hosein Zomorshiridi, Iran's Tling, Tehran 2006, pp. 69-71.

6 Venetia Porter, Islamic Tiles, Tehran 2010, pp. 21-62.

7 Mahmud Maherolnaghsh, Motif Design and Implementation in the Iranian Tile Work in the Islamic Period, vol. 2, Tehran 1983, p. 8.

8 Mahmud Maherolnaghsh, Tile and its Application, Tehran 2002, pp. 40-69. 
their chemical formulas in each stage. ${ }^{9}$ Holakooei and others in the article entitled, "Haft rang or Cuerda Seca? Spectroscopic Approaches to The Study of Overglaze Polychrome Tiles from Seventeenth Century Persia," compared Haft rang tiles in the Safavid era and cuerda secas. After a description and comparison between them, the main feature of the article provide information about chemical method of making Haft rang tile and cuerda secas. ${ }^{10}$ In Hans E. Wulff's book, The Traditional Crafts of Persia: Their Development, Technology and Influence on Eastern and Western Civilizations, the traditional crafts of Persia, which include a wide range are completely illustrated. ${ }^{11}$ Greg Daly, in his book entitled Developing Glazes, demystify the process with practical advice and complete, step-by-step instructions. He covers all the essentials, from planning recipes and recording results to mixing glazes and finding the correct firing temperature. ${ }^{12}$

In his book, Architecture of the Pahlavi I Era (Transformation of Thoughts, the Emergence and Formation of the Twenty Years of Iranian Architecture from 1920 to 1941), Kayani addresses the transformation of cities, the use of new materials in the construction of buildings, and the tendency of Reza Shah and the architects of that time toward modern architecture and how it is implemented..$^{13}$ In another book entitled Iranian Architecture in the Pahlavi Era, Rajabi deals with the process of the formation of new events and a new style of architecture in the first Pahlavi era. ${ }^{14}$ Another book, Contemporary Iranian Architecture written by Bani Masoud discusses confrontation of Iran with the modern world and its impact on contemporary Iranian architecture from the Qajar period to three decades after the Islamic Revolution. ${ }^{15}$ Ghobadian, in his book, Stylistics and Theoretical Foundations in Contemporary Iranian Architecture," examines the first and second Pahlavi periods and categorizes the types of architectural styles used in this era, which are often a compilation of Iranian historic architecture and contemporary western architecture. ${ }^{16}$ Maryam Montazer in her master thesis entitled, "Investigating the Effects of the Transition from Tradition to Modernity (modernism) on the Formation of Shiraz's Residential Architecture and its Adornments", examines changes in facade decorations of residential buildings and

9 Mehdi Alawi, Tile: Searching for the Missing Sciences and Techniques of the Ancient Iranian Forgotten Arts, 2011, pp. 153-155.

10 Parviz Holakooei and others, "Haft Rang or Cuerda Seca? Spectroscopic approaches to the study of overglaze polychrome tiles from seventeenth century Persia," Journal of Archaeological Science, Vol. 41, 2014, pp. $447-460$.

11 Hans E. Wulff, The Traditional Crafts of Persia, Cambridge 1966, p. 20.

12 Greg Daly, Developing Glazes, London 2018, pp. 25-52.

13 Mostafa Kayani, Pahlavi I Era Architecture: Transformation of Thoughts, the Emergence, and Formation of the Twenty Years of Iranian Architecture from 1920 to 1941, Tehran 2004, pp. 233-256.

14 Rajabi Parviz, Iranian Architecture and the Pahlavi Era, Tehran 1976, pp. 65-157.

15 Amir Bani Masoud, Contemporary Iranian Architecture (The Struggle Between Tradition and Modernity), Tehran 2012, pp. 190-287.

16 Vahid Ghobadian, Stylistics and Theoretical Foundations in Contemporary Iranian Architecture, Tehran 2013, pp. 141-237. 
the way the plans of residential building is changed from introversion to extroversion. ${ }^{17}$ In the article entitled "Romanticism in Contemporary Iranian Architecture" (With Emphasis on the Architecture of the Pahlavi II Period After 1962), Mirinezhad examines the reasons for the promotion of romanticism in the architecture of the Pahlavi era. He regards architects' attempts to use national symbols and nationalism as the reason for naming the Pahlavi era architecture as "Romantic architecture". ${ }^{18}$ In his thesis entitled "In the Search for House Construction Models of Late Qajar Period and The Pahlavi I Era in Mashhad, With an Approach to the Architectural Aspects of Works", Davarpanah studied house construction models in the late Qajar period and the Pahlavi I period and provided explanations about changes in the architectural models from the Qajar period to the Pahlavi period and houses that were built in Mashhad. ${ }^{19}$

In his book Shiraz in the Past and Present, Emdad introduces the gardens in Shiraz, which are generally from the Qajar and the Pahlavi periods, and the mansions built in gardens. ${ }^{20}$ Mostafavi in the book entitled Land of Pars, provides a review of Fars Province and discusses the history of the construction of Shiraz and its famous and old places. ${ }^{21}$ In a study on the physical-spatial expansion of Shiraz, Abdollahzadeh Fard described the expansion stages of Shiraz from the Zand period to the end of the Pahlavi period and has divided its physical-spatial expansion in the Pahlavi period into three periods. ${ }^{22}$ In another study, Zekri and Ranjbar explored the growth of Shiraz between 1957 and 2002. ${ }^{23}$ Jafarpour, in his thesis entitled, "Modernization Representation in the Pahlavi I Era from the Perspective of Karim Khan Zand Street of Shiraz", provided a detailed analysis of the development of Shiraz during the Pahlavi I period and its social representation. ${ }^{24}$ In his thesis, "House in the Shirazian World: A Search for the Relationship Between Houses and the Culture of Residence

17 Maryam Montazer, Investigating the Effects of the Transition from Tradition to Modernity (Modernism) on the Formation of Shiraz's Residential Architecture and its Adornments, Master's Thesis in Art Research, Faculty of Arts and Architecture, Shiraz University, Shiraz 2014, pp. 170-264.

18 Shoheil Mirinezhad, "Romanticism in Contemporary Iranian Architecture (With Emphasis on the Architecture of the Pahlavi II Period after 1962)", Fine Arts, 18 (1), 2013, pp. 91-102.

19 Saed Davarpanah, In the Search for Construction Models of the Late Qajar Period and the Pahlavi I Era in Mashhad with an Approach to the Architectural Aspects of Works, Master's Thesis in Architecture, Islamic Azad University of Mashhad, 2015, p. 75.

20 Hasan Emdad, Shiraz in the Past and Present, Shiraz 1961, pp. 98-110.

21 S. Muhammad Taghi Mostafavi, Land of Pars, Tehran 1964, p. 205.

22 Ali Reza Abdullahzadeh Fard, "Effective Factors and Directions of Physical-spatial Expansion of Shiraz from 1921-2003," Proceedings of The Scientific and Specialized Projects of Urban Development and Architecture of the Provinces of the Country, Center for Study and Research on Urbanization and Architecture, Tehran 2005, pp. 313-314.

23 A. Zekri, H. Ranjbar, "The Growth of Shiraz Between 1957 to 2001 Using Remote Sensing and Geographic Information System," Proceedings of the Scientific and Specialized Projects of Urban Development and Architecture of the Provinces of the Country, Center for Study and Research on Urbanization and Architecture, Tehran 2005, p. 79.

24 Ali Reza Jafarpour, Modernization Representation in the Pahlavi I Era from the Perspective of Karim Khan Zand Street of Shiraz, Master's Thesis in Architecture, Shahid Beheshti University of Tehran, 2012, p. 113. 
in Shiraz During the Qajar period", Esmailzadeh investigated the architectural design of the Qajar houses, and provided the reasons for the existence of these decorations in the houses. ${ }^{25}$

\section{The Expansion of Shiraz in the Pahlavi Era}

The physical-spatial texture of Shiraz is divided into two categories: historical (old) and new textures. The old texture was constructed in the early Islamic period until the Qajar period and the new texture is related to Shiraz in the contemporary era. The texture of Shiraz in the Pahlavi era is also referred to as the middle texture. ${ }^{26}$ During the Pahlavi I period, the city of Shiraz expanded around the old neighborhoods by constructing wide boulevards and streets. The middle area of Shiraz expanded quickly, and modernity measures in Iran in 1921 caused the most significant changes in the structure of the city from a spatial perspective. The streets constructed in this period were Karim Khan Zand, Lotf Ali Khan Zand, Naser Khosrow, Roodaki, Ahmadi, Qaani, Manouchehri, and Pahlavi. ${ }^{27}$ Afterward, Nader Street was expanded to the current Bushehr terminal and Karim Khan Zand was developed from Setad Square to Namazi Hospital. ${ }^{28}$ Considering the urban development and the spread of houses, attention has been paid to the location of the houses. Fig1. shows the spread of selected houses in Shiraz and Table1. below the picture shows more details about numbers and location of selected houses:

25 Davud Esmailzadeh, House in the Shirazian World: A Search for the Relationship Between Houses and the Culture of Residence in Shiraz During the Qajar Period, Master's Thesis in Architecture, Shahid Beheshti University of Tehran, 2011, p. 245.

26 Ebrahim Jamali, Survey and Demarcation of Shiraz, Master's Thesis in Urban Planning, Faculty of Arts and Architecture, Shiraz University, 2001, p. 79

27 Ali Reza Abdullahzadeh Fard, Op. cit, p. 313.

28 Behruz Razmjouei, Investigating the Process of Integrating Rural Areas into Urban Centers: Case Study of Shiraz, Master's Thesis in Urban Planning, Faculty of Arts and Architecture, Shiraz University, 2005, p. 65. 


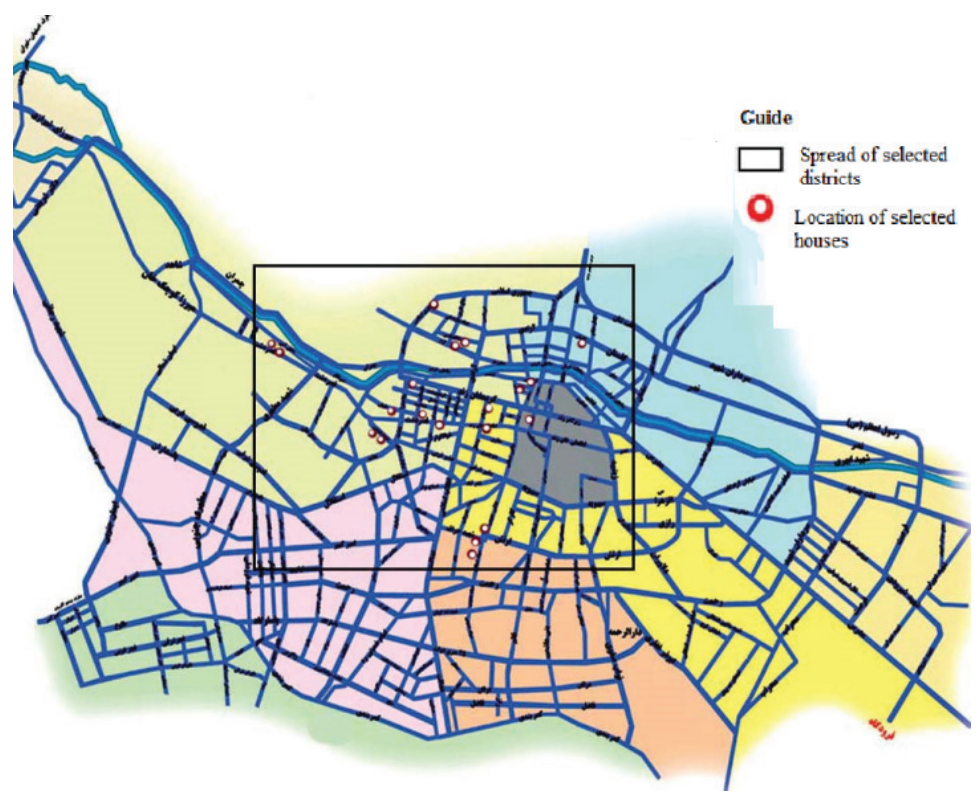

Fig. 1. The spread of selected houses in Shiraz www.reza-mohammadian.ir

\begin{tabular}{|c|c|c|c|c|}
\hline \multirow{2}{*}{ NO } & \multirow{2}{*}{ Owner } & Address & \multicolumn{2}{|c|}{ Number of Haft rang frames } \\
\cline { 4 - 5 } & & Zand ST. Anvari ST. & 5 & 2 \\
\hline 1 & Shapoori & LotfAli Khan Zand ST. & & 2 \\
\hline 2 & Unknown ${ }^{29}$ & Artesh SQ & 4 & 4 \\
\hline 3 & Javanmardi & Jomhoori Eslami ST. & & 2 \\
\hline 4 & Unknown & Eram ST. & & 4 \\
\hline 5 & Asnaf school & Molasadra ST. Hedayat ST. & & 1 \\
\hline 6 & Unknown & Zand ST. Saadi ST. & & 2 \\
\hline 7 & Unknown & Artesh ST. & & 1 \\
\hline 8 & Unknown & Shahid Beheshti ST. & & 1 \\
\hline 9 & Samadani & Ghasraldasht ST. & & 7 \\
\hline 10 & Hamoonnavard & Zand ST. Khayyam ST. & & 2 \\
\hline 11 & Saraf Zade & Molasadra ST. Khalili ST. & & 3 \\
\hline 12 & Unknown & Artesh ST. & & 9 \\
\hline 13 & Azadi & Ghasraldasht ST. & & 1 \\
\hline 14 & Mosleh & Shahid Beheshti ST. & & 4 \\
\hline 15 & Unknown & Ghasraldasht ST. & 1 & 1 \\
\hline 16 & Homayoon & Zand ST. Roodaki ST. & & 2 \\
\hline 17 & Unknown & Northern Sepah ST. & 2 & 1 \\
\hline 18 & Rezaii & Khakshensi ST. & & \\
\hline 19 & Unknown & Atlasi ST. & & \\
\hline 20 & Unknown & selected view & \\
\hline
\end{tabular}

Table 1. 20 selected houses to study in Shiraz

(Table collected and edited by Dordaneh Mohammadi, 2017)

29 Some of owners do not tend to be known so houses are known by numbers. 


\section{The Architecture of Houses Constructed in Shiraz in the Pahlavi Era}

Iranian architecture is a modern architecture that can be traced back to the architecture of the Qajar era. One of the hallmarks of the architecture of this period was introversion. The attitude dominating the Pahlavi era and the sociopolitical and architectural developments led to the facade and the space of buildings spinning from within to the exterior. ${ }^{30}$ Several reasons can account for the emergence of modernism, the most important of which was the prevalence of western patterns and intellectual tendencies of Iranian academia educated in the West. In addition to modernism, archaism was one of the main trends of this period, which was formed following archeologists' activities and their achievements. Also, the emergence of the German neoclassical style, especially in government buildings, was one of the other trends, which brought attention to ancient architecture and its nostalgic aspects. ${ }^{31}$

These tendencies, considered to be essential in building state-owned buildings, crept over time into private buildings and personal houses. Local architects began to build houses of this type by looking at and inspired by government buildings. Shapouri house is one of the houses in Shiraz constructed in this period and is decorated with respect to the ancient Iranian architecture. The exterior and interior view of the house are decorated with many decorative items such as stucco, tile work, brickwork, mural paintings and wood carvings (as a decorative item) and other house decorations. Some of the motifs and patterns in these decorations date back to the Achaemenid period from an archaistic point of view.

During the Pahlavi I era, brick decorations became more prevalent because of the speed and ease of construction. The architecture of this period was simplified and revolutionized compared to the previous periods. However, its decorations were reminiscent of the past. The entrances, corners, ceilings, windows, edges and upper edges of buildings, and top of the windows had decorations that sometimes were designed according to the ancient, and sometimes western and modern patterns, and sometimes were based on the decorative patterns of the Islamic period. ${ }^{32}$

The Pahlavi I era was the era of the emergence of modern Iranian architecture, and the Pahlavi II era can be considered as the period of development and promotion of modern Iranian architecture. ${ }^{33}$ In this period, due to the development of cities, many buildings including houses were built with a modern approach. ${ }^{34}$ In the modern period and in the Pahlavi II buildings, spatial diversity was reduced quantitatively and

30 Saed Davarpanah, Op. cit., p. 75.

31 H. Kamelnia, M. J. Mahdavinezhad, Introduction to Contemporary Architecture from East to West and Examination of the Fundamentals and the Origins of its Formation, Tehran 2012, p. 226.

32 Mostafa Kayani, Op. cit., p. 34.

33 Mostafa Kayani, Op. cit., p. 230.

34 Sirus Bavar, A Look at the Emergence of New Architecture in Iran, Tehran 2009, p. 86. 
qualitatively, and the area of houses and spatial and decorative diversity decreased. ${ }^{35}$ The construction and facade of buildings in this period were made of rock or cement; this influence come from Western architecture. Stone-built construction had affinities with archaeological approaches and was sometimes closely followed by the Achaemenid architecture and stone carvings. ${ }^{36}$

The houses built in this period in Shiraz are often one or two-floor houses, they have a courtyard and in some cases, the building entrance has cement or rock facades. The exterior facades of houses are covered with cement without any decoration and there are very few examples with tiled frames on the portal. Houses with exterior rock facades have more decorations, which indicate their owners and builders financial ability to afford traditional arts.

The decorations of the buildings were much smaller than those in the Pahlavi I era, and only visible in some buildings. Architectural extraversion led to the emergence of decorative elements in the exterior of the houses, as in most cases the interior space of the house lacks decoration. For example, the mirrored muqarnas (which was an interior ornament) was transferred to the head at the entrance of the building. Haft rang tile frames were installed in various places around the exterior of the house. The stucco capitals and mosaic-tiled window frames were located in the street view (in the past they were in the interior view of the house), and in some houses the interior was very simple in design. There are fewer houses with mural paintings, and in a few existing examples, paintings are located on the ceiling borders. The stuccos used to decorate the ceiling were simpler than those used in previous periods, and there was a preference for simplification and the modern style in some decorations.

35 Maryam Montazer, Investigating the Effects of the Transition from Tradition to Modernity (Modernism) on the Formation of Shiraz's Residential Architecture and Its Adornments, Master's Thesis in Art Research, Faculty of Arts and Architecture, Shiraz University, Shiraz 2014, p. 179.

36 Mostafa Kayani, Op. cit., p. 238. 


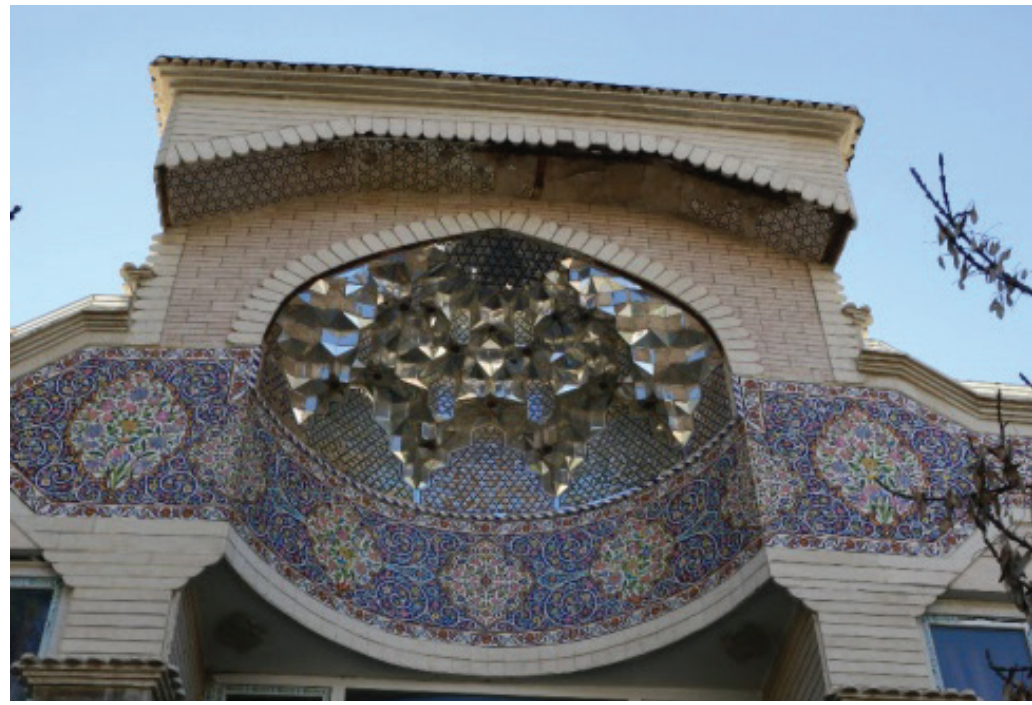

Fig. 2. Muqarnas, mirrored decorations, and Haft rang tiles in the exterior view of a house in Jomhoori Eslami ST. In Shiraz built in the Pahlavi era (Photo by Dordaneh Mohammadi, 2016)

\section{Making Haft Rang Tiles in Shiraz in the Pahlavi Era}

In the production process of Haft rang tiles, art and industry are mixed and the craftsman serves as both an artist and artisan because tiles and all the tools and materials needed were made using the traditional method in the Haft rang workshop up to the end of the first Pahlavi era. A thing that distinguishes Haft rang tiles from other tiles is the colors used to embellish them. These colors which are made in the form of glaze are as follows: 1) White, 2) Yellow, 3) Red, 4) Green, 5) Turquoise, 6) Azure, 7) Brown, 8) Black, and 9) Golden. Besides, mixed colors have been used to produce these tiles including pink, dark and light purple, and beige.

To produce Haft rang tiles, the cooked tiles are arranged together in the required sizes to be painted. The design of the tile is transferred both directly and indirectly. Some miniature and landscape images and calligraphy texts are transmitted directly to the tile. In the indirect method, a paper which is equal to the tile frame in size is prepared and the intended imaged is drawn on it and the drawn image is embroidered on the white paper. Then, the embroidered design is transferred to the tile surface by a charcoal bag. After that, the transferred image is drawn via black color with a special brush. After finishing the design, the tiles are painted with glaze colors and after drying, the tiles are numbered and cooked in the furnace. Raw tiles (before being fired in the kiln) and colors used to paint the tiles were traditionally produced in workshops until the first half of the second Pahlavi era, but after the 1960s colors were imported from Germany and Italy and were used in the tiling industry. In addition, $15 \times 15 \mathrm{~cm}$ 
tiles were exported from Qale Morghi in Tehran to other cities. Tile workers in Shiraz used to cut these tiles in $14 \times 14 \mathrm{~cm}$ dimensions (called making fourteen in colloquial terms). To do so, each side of the tile was cut by half a centimeter so that the length of each side was decreased from 15 to $14 \mathrm{~cm}$. This was done for two reasons: First, the tiles to be flat on four sides, and second, the tile should fit seamlessly when installed next to each other.

Haft rang tiles are manufactured in a similar manner in all regions of Iran, and the only difference in the construction of Haft rang tiles in Shiraz as compared to other Iranian cities is in the use of locally-available materials.

\section{Features of Haft Rang Tile Decorations in Houses Constructed in Shiraz in the Pahlavi Era}

In the Qajar period, Haft rang tiles were used to decorate public places such as mosques, schools, and gathering places. They were also used in private places like houses, and this trend continued throughout the Pahlavi era. With growing trends toward modern design and the construction of houses affected by this style, Qajar patterns declined and the use of decorations in building was also inspired by modern patterns. In the shift from introversion to extraversion, decorations in addition to the interior view were installed in the exterior view (which was not commen in the past) as well. In the buildings constructed in the Pahlavi I era, decorations can be seen on wooden canopies and on the walls of the main building, and in the Pahlavi II era, Haft rang tile frames have been used in interior and exterior facades.

Exterior decorations are used in several places such as portals, between the floors, the front of the building, adjacent to the entrance door, between or above the windows on the balcony or even a large part which made the full view of the building, and sometimes serve a decorative function or a part added to the building, and Haft rang tiles are placed on it.

In the interior view of a large number of houses, Haft rang tiles are placed in the greenhouse (a place for keeping plants inside the houses), and in some cases, they can be seen on the hall or lobby wall. The tile frames in a house were in the form of a narrow strip along the wall reaching to the ceiling and encircling the reception hall as well as the corridor )Fig. 3). The decorations of tile frames have different dimensions and sizes, and sometimes the Haft rang tile frames start from the greenhouse on the ground floor and end near the ceiling of the first floor. 


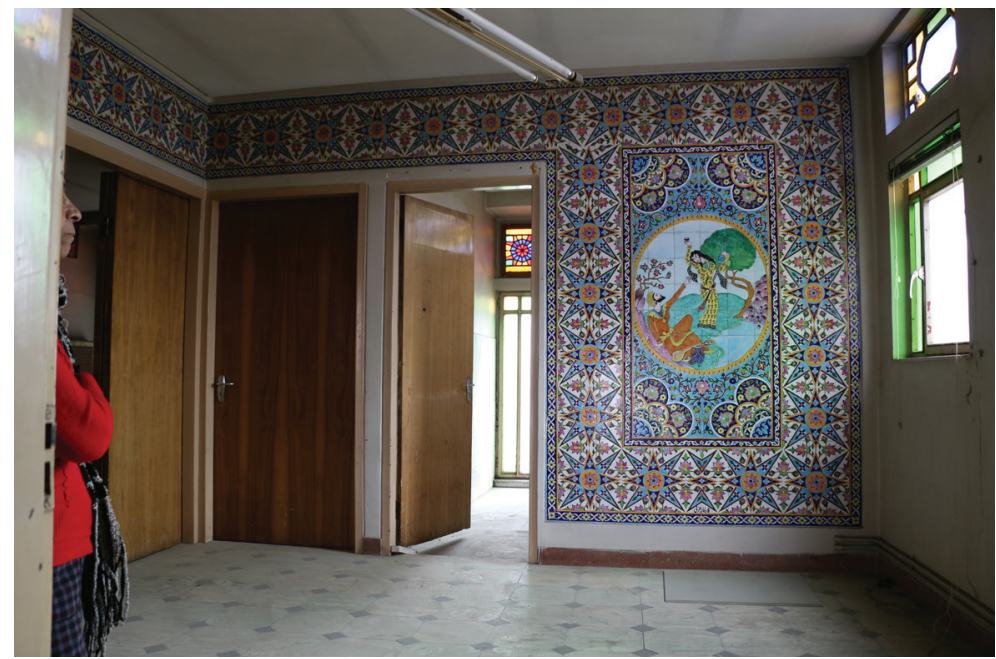

Fig. 3. Haft rang tile in the form of a narrow strip along the wall in house NO.3 in Artesh SQ.

(Photo by Dordaneh Mohammadi, 2016)

\section{Shape Variations in Decorations of Haft rang tiles}

Haft rang tiles are located in different places in the houses constructed in Shiraz in the Pahlavi Era. Because of this, the tile frame has different shapes, depending on its location. There are 53 tiles in the sample under study, which are divided into 8 categories:

1) Rectangles, 2) Squares, 3) Deformed vertical rectangle 4) Curved surfaces, 5) Vertical diagonal frames, 6) Window frames, 7) Composite geometric shapes, and 8) Crowns. 


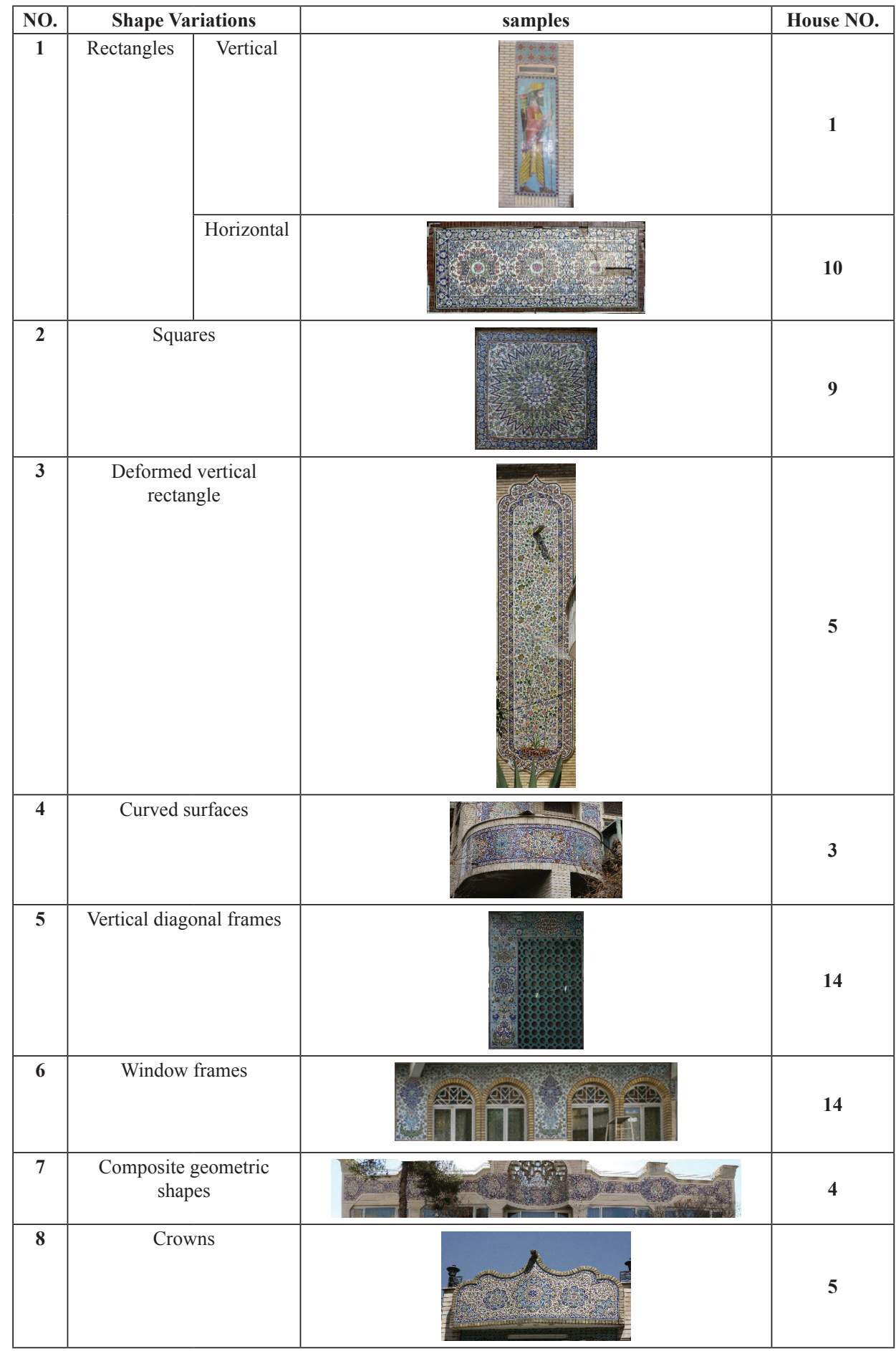

Table 2. Shape variation samples

(Table collected and edited by Dordaneh Mohammadi, 2019) 
Haft rang tiles are rectangular in a large number of houses built in the Pahlavi era, while there were only a few in the form of squares or curved surfaces. Haft rang tiles are designed in a semicircle form and installed in the frameworks of curved surfaces according to their positions. This shape of the tile frame is often used in the terrace view.

The reason for naming the vertical diagonal tile frame as such, is that the two sides of the rectangle with a 90-degree angle form a tile shape. This type of tile shape has different forms and sizes, and the shape of the tile frame does not restrict the design of the plan and the ability to implement different designs. Composite geometric shapes, large medallions, window frames, and crowns have been named based on the type and shape of the frames. This type of framing illustrates the possibilities that Haft rang tiles that the artist-artisans has in this field, which, in addition to the variety of designs and colors in tile frames, enables them to work freely and design their desired patterns.

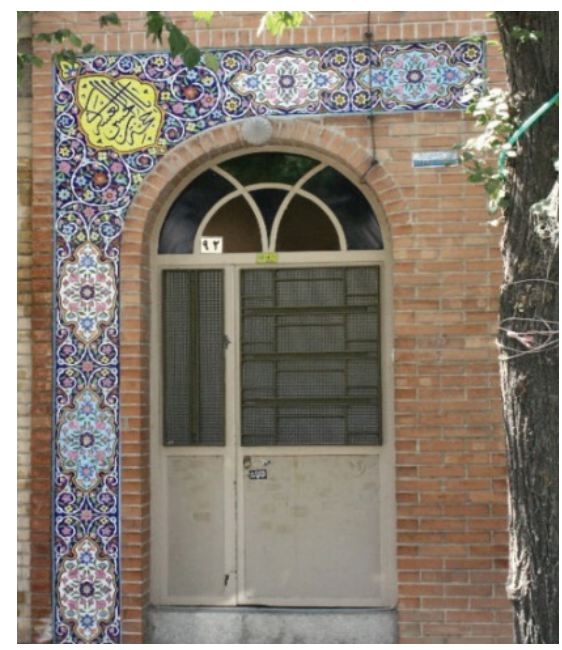

Fig. 4. The use of vertical diagonal framing in the entrance view of a house built in Khakshenasi

ST. in the Pahlavi era (Photo by Dordaneh Mohammadi, 2016)

\section{Color Variations}

The traces of the Qajar color variations can be seen in the Pahlavi era. What distinguishes Shiraz tiles from other samples is the use of warm colors, color variations, dark and bright contrast, complementary color contrast, and color harmony. In this period, black was used for lining margins or medallions and in some cases to paint surfaces. The dominant green color in the Qajar period changed to small and scattered green surfaces in the tile frame. Yellow was also used in a similar way. In addition to the features mentioned above regarding the color of Shiraz tiles, the color indexes of Isfahan were added to tiles in the Pahlavi era and colors such as azure and turquoise were used at 
high levels as main background colors. Many red flowers changed into flowers with a lot of color variations. In this period, khatai flowers portrayed in many different colors. Harmony and light and dark contrasts are also seen in paintings from this period. Painting of animals in this period seems more realistic than the previous periods.

The use of rose or red flowers became less frequent in the Pahlavi period and khatai flowers designed in many different colors. In the designs of this period, the design and color variations of the flowers created a form of tile framing that is different from those of the previous periods. Other elements that were available in previous periods and continued to be used in the Pahlavi period were European elements. These elements were depicted in the Qajar period in the form of pots or pillars on either side of medallions or European scenes in the decoration of pots and medallions, or were drawn independently. In some cases, there are ribbons between the medallions or below them. During the Pahlavi era, the use of European landscapes was continued, but they are mostly seen in pot decorations.

In the design of tile motifs and patterns, one-second, one-fourth, and one-eighth symmetries were used, with the one-fourth symmetry being the most widely used one. The symmetries and similarity of paired tile frames have been observed in the Pahlavi era. And in a small number of studied samples, non-symmetry is observed.

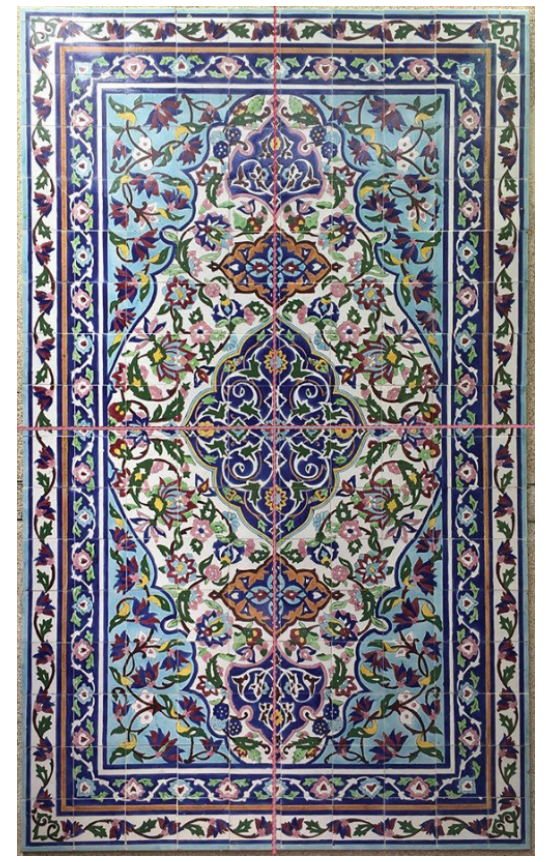

Fig. 5. The use of one-fourth symmetry in the design of tile motifs and patterns, House NO.16 constructed in Ghasraldasht ST. in the Pahlavi II era

(Photo by Dordaneh Mohammadi, 2016) 


\section{Haft rang Tiling Motifs and Patterns in Houses Constructed in Shira in the Pahlavi Era}

The tile artist of the Pahlavi era was the hereditary artist of the ancient times, especially tile artists of the Zand and Qajar periods. Design motifs on tiles were inspired by the tile designers from the buildings of the mentioned periods and the craft that was passed down by teaching from the master to the apprentice. Plant designs play a dominant role in Haft rang tiles in the Pahlavi era in Shiraz. These motifs are often found on the margins and the main design of the tiled frame in the form of flower and bird, floral, eslimi-khatai, and medallion motifs and patterns.

\section{Plant Motifs}

The dominant motif in Haft rang tiles of the Pahlavi period in Shiraz include herbal designs and patterns that are found in the form of floral, flower and bird, eslimi-khatai and medallion motifs, and these motifs form the borders and main design of the tile frame. A group of motifs featuring flower and bird and floral designs have been drawn realistically, with some flowers and plants similar to their natural species. The other group includes abstract designs and motifs such as eslimi-khatai and medallion patterns. There are also exceptions to medallions, in which realistic motifs of flowers have been used.

With the election of Shiraz as the capital of the Zand dynasty, this city became a manifestation of many arts. Architectural monuments of Shiraz were decorated with various types of tiles and marble pedestals, grid designs, flower bouquets, and intricate flowering plants. ${ }^{37}$ The use of plant motifs and themes continued in Qajar architecture. Examples include: Zinatalmoluk Qavami House, Narenjestan or Qavam Garden, and Manteqi Nezhad House. The Pahlavi period also used such architectural decorations in spite of the evolution of architecture.

\section{Eslimi-Khatai Motifs}

The term Eslimi derived from Islam and refers to arabesque designs. Eslimi motifs are used in conjunction with floral designs that are called Khatai, ${ }^{38}$ and their thickness is 3 to 1 in proportion to the Khatai node. Eslimi motifs, in addition to having a geometric and mathematical basis, are also based on the mysteries of nature and are a reminder of the spring season or the season of growth. ${ }^{39}$ In half of the Haft rang tile frames in the samples under study related to the Pahlavi era, Eslimi motifs designed independently and sometimes in the form of paintings inside medallion motifs. In

37 Leila Soudavar Diba, "Flower and Bird Motifs", Month Art Book, 160, 2011, pp. 46-57.

38 Hadi Hazavei, "Visual Arts: Eslimi, Forgotten Language", Quarterly Journal of Art, 6 (91), 1984, p. 91. 39 Hadi Hazavei, Op. cit. p. 99. 
most of the tiles in this study, the Eslimi lines were white and green in color. Fig. 6. illustrates an example of Eslimi motifs used in Haft rang tiles. Eslimi-Khatai composition is used in less than half of the motifs of the tile frames. More attention paid to Eslimi motifs in the Pahlavi era in Shiraz because khatai and floral motifs were found to be more common than other patterns in the tile frames produced in the Qajar era. In the samples under analysis, Khatai was found to be the dominant motif and has been used in almost all the tile frames. This motif can be found as a dominant motif in a tile frame in the margin of other tile frame in the form of decorating geometric patterns, or as medallions in another tile frame. In the samples studied in Shiraz, following the old works, one of the main components of these decorations was the role of rose or red flowers, which were touched on earlier in this paper. Khatai motifs in tile frames of the Pahlavi era have high color variation from the smallest leaves to the large shah abbasi flowers.

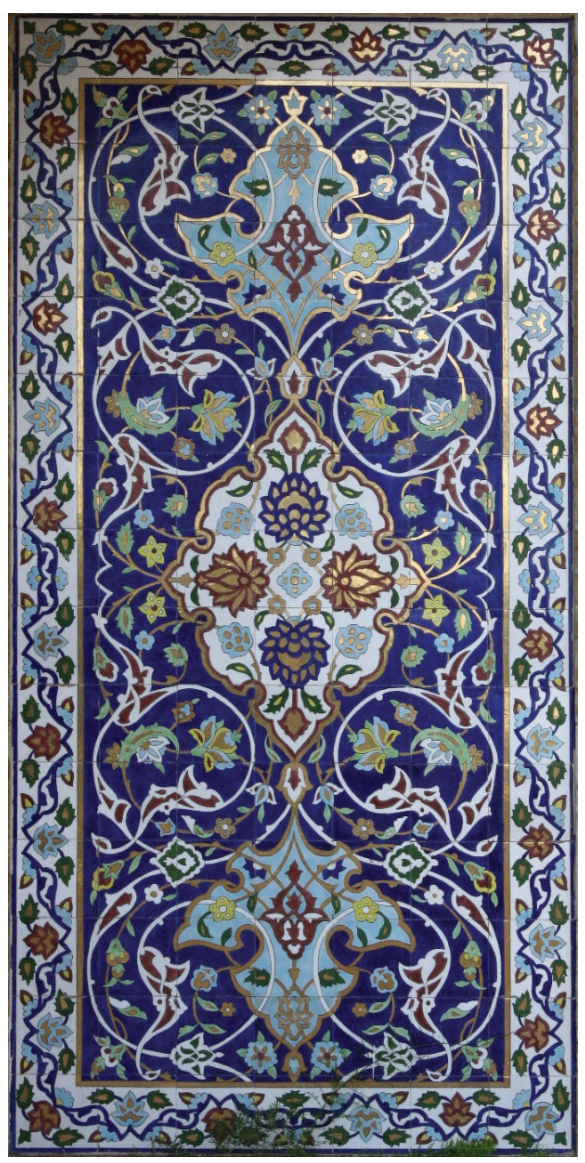

Fig. 6. The use of Eslimi-Khatai motifs in the frame of Haft rang tile in the entrance view of House NO. 10 in Ghasraldasht ST. in the Pahlavi II era

(Photo by Dordaneh Mohammadi, 2016) 


\section{Bird and Flower Motifs}

The "Flower and bird" and "floral" motifs in the Haft rang tile frames of the Pahlavi period show a very diverse pattern with many flowers drawn in a variety of different angles and colors. Open and semi-open buds have also been used in the tile frames, and they display different stages of a flower from the closed buds to the completely open flowers. In some of the tile frames, there are flower motifs in the form of "single flowers" in a medallion. The flowers have been drawn in different shapes and in different ways, with a few realistic motifs. For example, a single flower has been drawn with a number of petals and with a different color (Fig. 7). In the "floral" and "flower and bird" motifs, there are different types of flowers such as: lotus, narcissus, shah abbasi, hundred-leaved rose, tagete, iris, and pentas lanceolata. Among the sample motifs, a few of the tile frames have been decorated with floral, and flower and bird motifs.
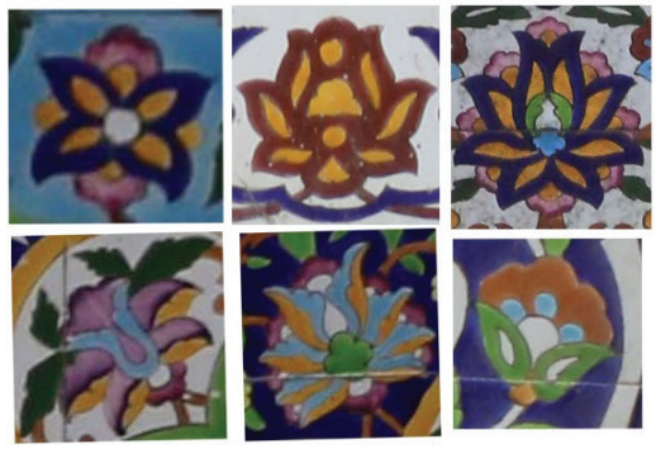

Fig. 7. A sample of khatai flowers (shah abbasi) in the houses built in the Pahlavi era in Shiraz (Photo by Dordaneh Mohammadi, 2016)

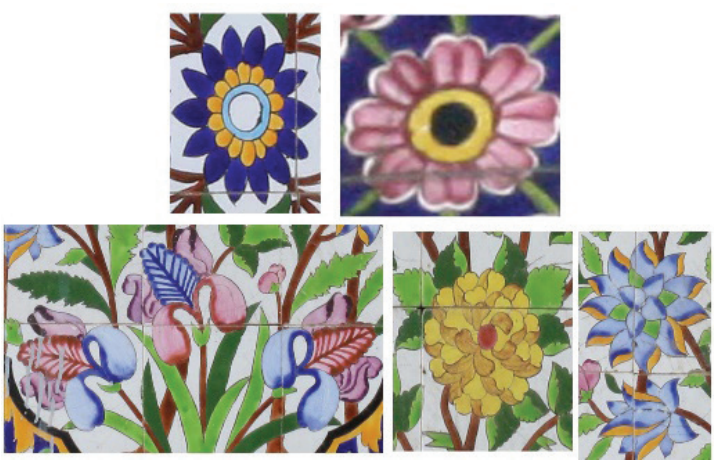

Fig. 8. A sample of lotus, narcissus, khatai flower, hundred-leaved rose, tagete, Irises, and pentas lanceolata flowerin the houses built in the Pahlavi era in Shiraz (Photo by Dordaneh Mohammadi, 2016) 


\section{Medallion}

The medallion is one of the main components of traditional design, which is usually placed in the center of the design and is often seen in various forms such as a circle, ellipse, rhombus, or a combination of several geometric shapes. Sometimes two smaller symmetrical designs with different forms of a larger medallion called a medallion head are placed on both sides of the medallion. A medallion head is usually crenate-shaped and in some cases has motifs like those used in the medallion. Generally, the medallion is designed with eslimi-khatai motifs. Sometimes, triangles and quadrant circles called corners are drawn around the medallion in the four corners of the design. ${ }^{40}$ In the studied samples, a sample is in the form of a quarter circle; in other cases it is a quadrant medallion.

In Shiraz, tile medalions are a basis for different drawings. For example, one can point out the poetic miniature motifs in the medallion, which have been drawn as geometric motifs, or medallion decorations with Eslimi motifs in a background that is made entirely of khatai motifs. Medallions and medallion heads are drawn in rows or columns in a variety of shapes.

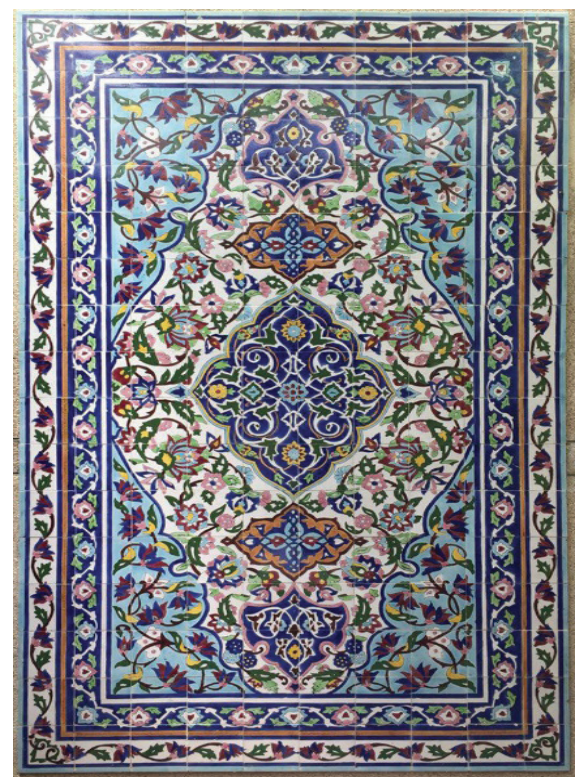

Fig. 9. The use of medallion motifs in Haft rang tile frames in the exterior view of the greenhouse of House NO. 16 constructed in the Pahlavi II era

(Photo by Dordaneh Mohammadi, 2016)

40 Azar Saffai, Investigation of Painting Decorations in Wooden Ceilings of Shiraz Houses During the Qajar Period, Master's Thesis in Art Research, Faculty of Arts and Architecture, Shiraz University, 2015, p. 204. 
Of 53 samples, 7 tile frames were constructed in Isfahan. The most important difference between Isfahan tile frames and the tile frames made in Shiraz is related to medallion motifs. In the sample from Isfahan, the medallion was drawn as a basis for the original medallion and they have more twisting lines, which differentiates their shape from those made in Shiraz.
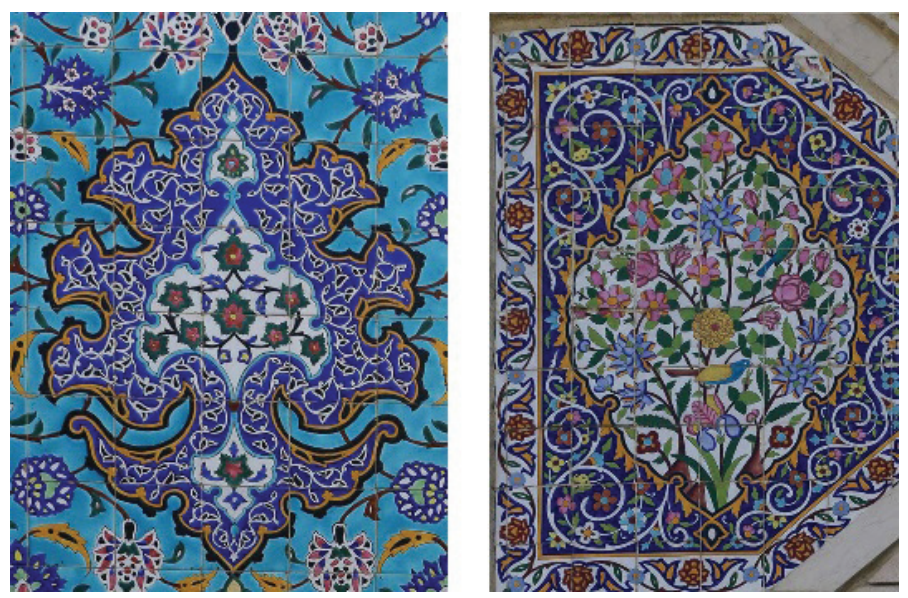

Fig. 10. The use of medallion in Haft rang tile frames made in Shiraz (on the right) and Isfahan (on the left)

(Photo by Dordaneh Mohammadi, 2016)

\section{Human Motifs}

Human motifs in the samples under analysis are divided into two categories: Archaistic motifs and miniature motifs. There are three archaistic human motifs in the tile frames, illustrating the Pasargad winged man, the Achaemenid soldier, and Audience Palace of Darius the Achaemenid, respectively. There are two miniature human motifs, one shows a woman and a man who are merrymaking in a natural setting next to a stream. The second miniature displays a woman who is holding a pitcher. In the present examples, there are two human motifs in the form of contemplative men with a book beside them. This kind of illustration can be traced back to the Herat School and the works of Kamal al-Din Behzad in his two-page illustrations depicting an imaginary scene or imaginary impression of a real event in the present or the past. ${ }^{41}$ Another example of human motifs is a picture of a hunting ground showing men and women on horses. 


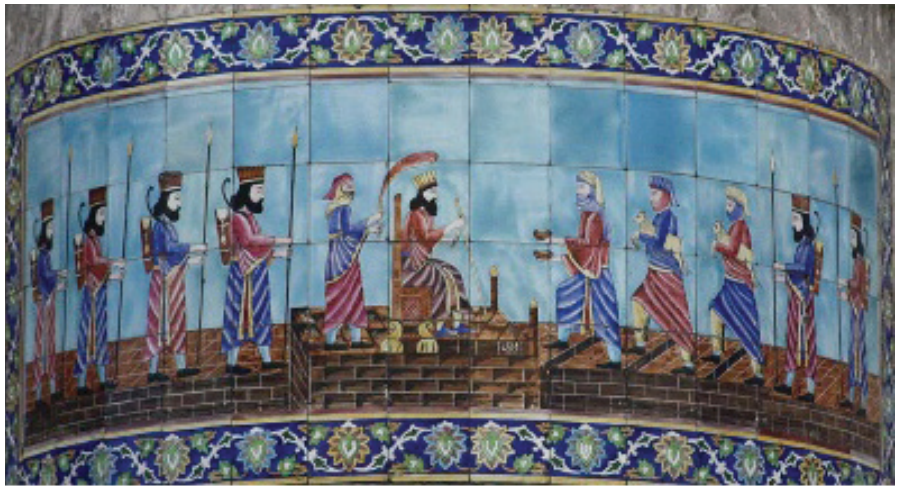

Fig. 11. The use of archaistic human motifs in house NO.12 in Khalili ST. in Shiraz constructed in the Pahlavi era

(Photo by Dordaneh Mohammadi, 2016)
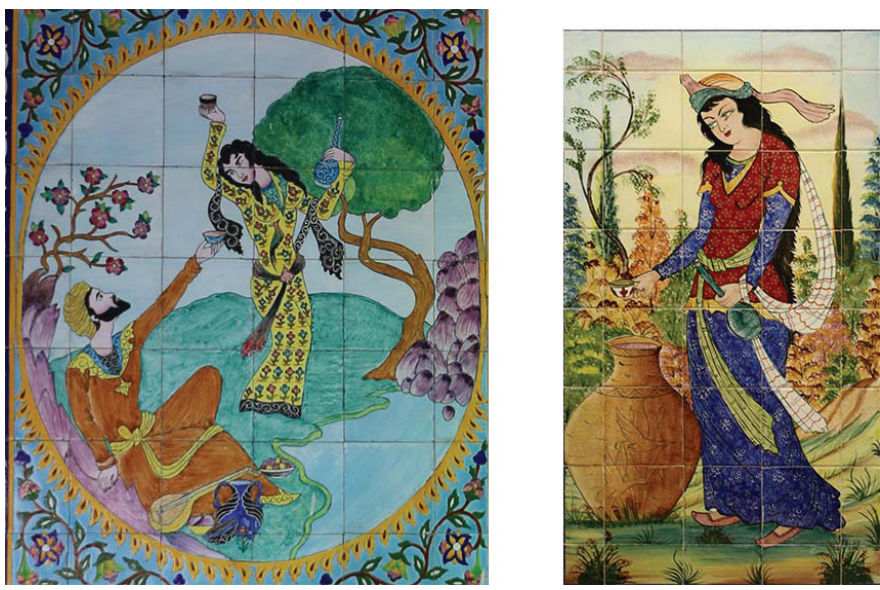

Fig. 12. The use of human motifs in 2 houses, in Haft rang tile frames made in Shiraz (Photo by Dordaneh Mohammadi, 2016)

\section{Animal Motifs}

The use of animal motifs has a history as long as the human history. Animals have played an important role in life and in artistic productions in different times. Various animal motifs have been painted on pottery containers and these motifs have evolved throughout history. ${ }^{42}$ Animal figures have been displayed as natural, abstract, or mythological portraits in paintings and even murals. Animal figures have also been used to decorate the Haft rang tile frame and are divided into two categories of birds and animals figures. Different types of butterflies and birds have been drawn in bird

42 Ardeshir Mojarad Takestani, Animal Design in Iranian Book Design Art, Tehran 2013, p. 9. 
and flower motifs, and also various animals have been drawn in the scenery and in hunting grounds.

Birds which are depicted in the flower and bird motifs have been drawn simply, and the artist tried to avoid drawing the bird's entire body volume by avoiding naturalism using a few shadows. Birds in the flower and bird motifs have been designed and displayed from different angles in different states, sometimes alongside other birds or near a butterfly. In some samples, birds are seen in the nest with chicks and among the floral motifs. Even in one sample, the bird is drawn on a Simorgh tile.

In the samples in this study, animal figures can be seen in groups in hunting scenes, with horses, deer, dogs, rabbits, and storks beside them. A tile frame shows a group of gazelles that are grazing, and another frame display the fight between a lion and a bull. This is a mythic motif modeling the prominent motifs in the Persepolis.

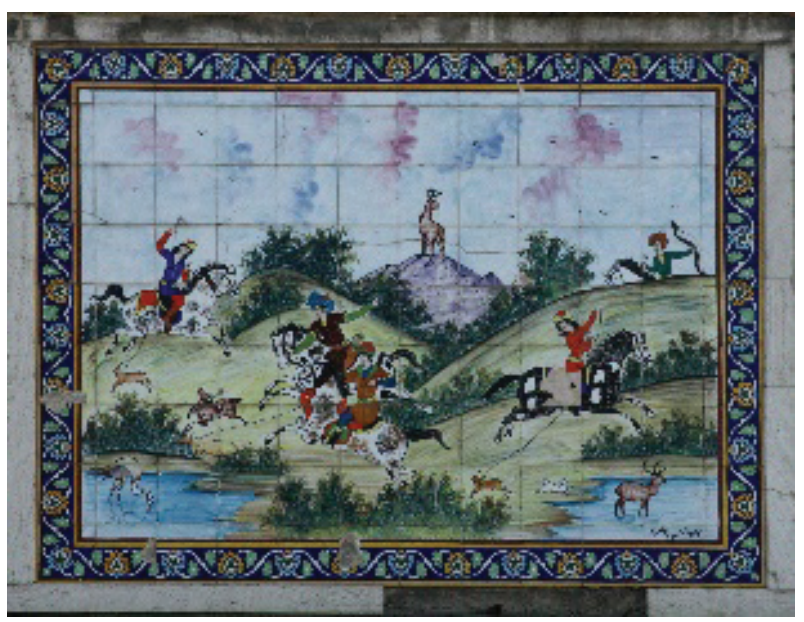

Fig. 13. The use of hunting scenes in the exterior of House NO.13 in Artesh ST. in Shiraz constructed in the Pahlavi II era

(Photo by Dordaneh Mohammadi, 2016)

\section{Natural Landscapes Motifs}

Natural landscapes motifs were designed in houses in the form of murals or Haft rang tile motifs in order to bring a piece of paradise into the interior of the house. In the existing samples, there are two scenic designs, one in the form of a circle decorated with motifs on a pot, and the other as a tiled frame for decorating the interior of the house. Landscape motifs are those motifs with miniatures or hunting grounds as their background and are characterized by a great variety in their design and motifs. Autumn trees, sunsets, ponds, rivers, mountains, and hills have been depicted in landscape motifs. 


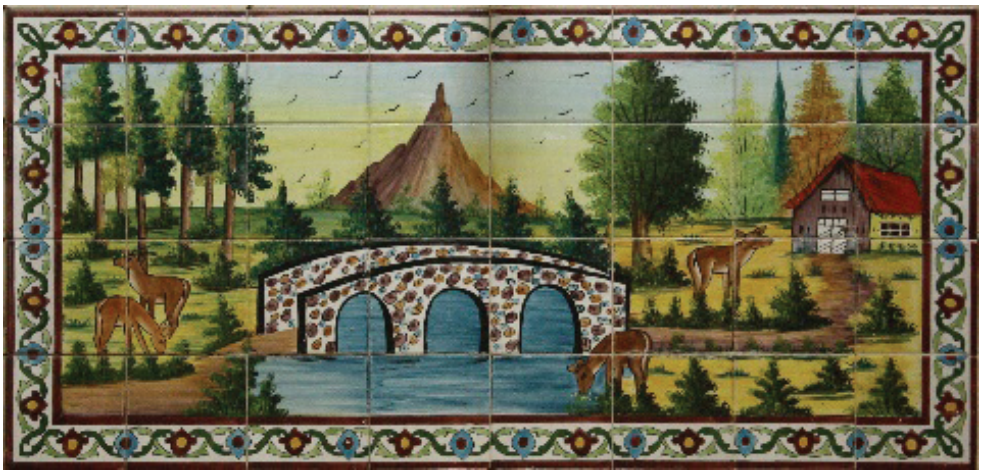

Fig. 14. The use of landscape in Haft rang tile frames in the interior view of House NO.18 in Artesh ST. in Shiraz constructed in the Pahlavi era

(Photo by Dordaneh Mohammadi, 2016)

\section{Geometric Motifs}

Geometric motifs can be considered the first human effort to represent the surrounding world in a symbolic manner. Traditional arts are based on geometrical motifs. In the tiles made in the period under study, nearly half of the motifs are geometric motifs. Among the motifs found in the studied samples are 10 and 16-sided Shamse and 4-sided star motifs. These types of motifs are also visible on the border of the tile frames.

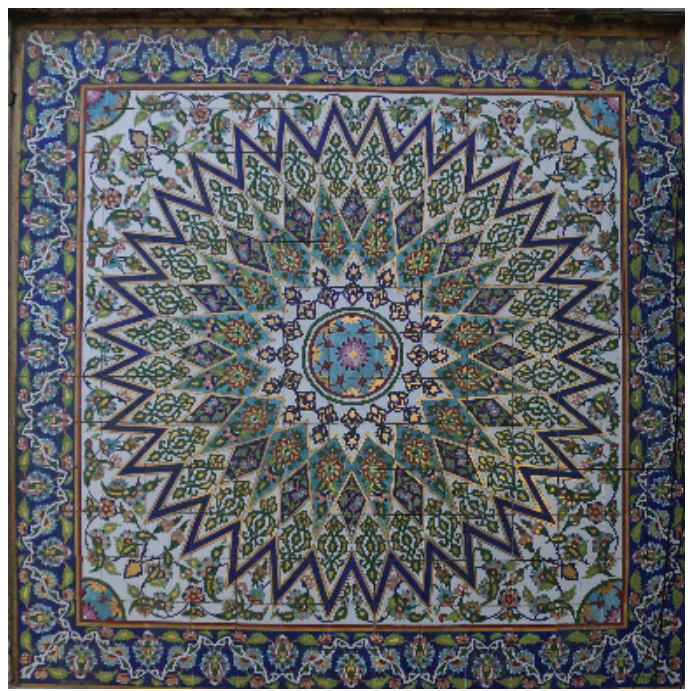

Fig. 15. The use of 16-sided shamse motif in Haft rang tile frames in the interior of House NO. 9 in Shahid Beheshti ST.

(Photo by Dordaneh Mohammadi, 2016) 


\section{Conclusion}

The decorative motifs on tiles used in the architecture of the houses constructed in Shiraz during the Pahlavi period include eslimi-khatai, flower and bird, and geometric motifs. Eslimi-khatai motifs are the most used motifs in the tile frames of this period and have been drawn in almost all Haft rang tile frames. Other motifs include flower and bird motifs. These motifs have sometimes been drawn all across the tiles and sometimes in a single medallion. These motifs are very similar to those found in the Zend era in Shiraz. Geometric motifs are also used in a few tile frames as the main background or marginal theme.

The existing Haft rang tile shapes in the interior views and exterior views of the houses under study are divided into eight categories, including: rectangles, squares, deformed vertical rectangle, curved surfaces, vertical diagonal frames, window frames, composite geometric shapes, and crowns (Table 2, page 11). These frames are in different dimensions and in harmony with the facade of the building. The motifs featured on the tile frames are aligned with the frame shape and cover the entire internal space of the frame. The shape of the tile frame does not constrain the design of motifs, and the coherence and proportionality of the motifs and the tile frames have created a balanced and dynamic composition.

Apparently, the color variation and combination of the Haft rang tiles in the architecture of the houses constructed in the Pahlavi period in Shiraz varied somewhat from the previous periods. In general, the use of warm colors during the Zand and Qajar period is observed more frequently than the Pahlavi period. The dominant colors in the background show that in the Pahlavi era, there was a tendency to use cool and neutral colors more than warm colors, and the designs are characterized by dark and bright contrast and complementary color contrast.

\begin{tabular}{|l|c|c|c|c|}
\hline \multicolumn{2}{|l|}{ color quality } & Zand & Qajar & Pahlavi \\
\hline $\begin{array}{l}\text { Color } \\
\text { variation }\end{array}$ & High & $*$ & $*$ & $*$ \\
\cline { 2 - 5 } Color & Low & $*$ & $*$ & \\
\cline { 2 - 5 } & Cold & $*$ & & $*$ \\
\cline { 2 - 5 } & Balanced & & $\begin{array}{c}\text { Black- Yellow- White- } \\
\text { Azur- Turquoise }\end{array}$ & White- Azur- Turquoise \\
\hline \multicolumn{2}{|r|}{ Background Color } & $\begin{array}{c}\text { Yellow- Azur- } \\
\text { Turquoise }\end{array}$ & $*$ & $*$ \\
\hline Contrast & $\begin{array}{c}\text { Sharpness and } \\
\text { Darkness }\end{array}$ & $*$ & & $*$ \\
\cline { 2 - 5 } & $\begin{array}{c}\text { Complementary } \\
\text { color }\end{array}$ & $*$ & & \\
\hline \multicolumn{2}{|r|}{ Color Harmony } & $*$ & & $*$ \\
\hline
\end{tabular}

Table 3. A comparison between quality of colors from Zand era until Pahlavi Era

(Table collected and edited by Dordaneh Mohammadi, 2017) 
The designs used in buildings constructed in Shiraz from Zand era to the end of the Pahlavi period illustrate the tendency of artists to use khatai motifs in tile frames. However, in the Pahlavi period, the use of Eslimi motifs increased under the influence of the designs used in Isfahan. Gradually, khatai flowers replaced by red and violet flowers in these designs. The use of cultural elements that were very common in the Qajar period in Shiraz turned into European landscapes in small dimensions in the Pahlavi era.

Grant Support: The author received no financial support for this work.

\section{References/Kaynakça}

ABDULLAHZADEH FARD, Ali Reza, "Effective Factors and Directions of Physical-spatial Expansion of Shiraz from 1921-2003," Proceedings of the Scientific and Specialized Projects of Urban Development and Architecture of the Provinces of the Country, Center for Study and Research on Urbanization and Architecture, Tehran 2005, pp. 295-317.

ALAWI, Mehdi, Tile: Searching for the Missing Sciences and Techniques of the Ancient Iranian Forgotten Arts, Academic Center for Education, Culture, and Research, Isfahan 2011.

BANI MASOUD, Amir, Contemporary Iranian Architecture (The Struggle Between Tradition and Modernity), Art of Century Architecture Publisher, Tehran 2012.

BAVAR, Sirus, A look at the Emergence of New Architecture in Iran, Tehran 2009.

DAVARPANAH, Saed, In the Search for Construction Models of the Late Qajar Period and the Pahlavi I Era in Mashhad with an Approach to the Architectural Aspects of Works, Unpublished Master's Thesis in Architecture, Islamic Azad University of Mashhad, 2015.

DALY, Greg, Developing Glazes, London 2018.

EMDAD, Hasan, Shiraz in the Past and Present, Shiraz 1961.

ESMAILZADEH, Davud, House in the Shirazian World: A Search for the Relationship Between Houses and the Culture of Residence in Shiraz During the Qajar Period, Unpublished Master's Thesis in Architecture, Shahid Beheshti University of Tehran, 2011.

GHOBADIAN, Vahid, Stylistics and Theoretical Foundations in Contemporary Iranian Architecture, Institute of Architect Science, Tehran 2013.

HAZAVEI, Hadi, "Visual Arts: Eslimi, Forgotten Language”, Quarterly Journal of Art, NO. 6, 1984, pp. 90-117.

HOLAKOOEI, Parviz; TISATO, Flavia; VACCARO, Carmela; PETRUCCI, Ferruccio Carlo, "Haft Rang or Cuerda Seca? Spectroscopic Approaches to the Study of Overglaze Polychrome Tiles from Seventeenth Century Persia," Journal of Archaeological Science, Vol. 41, January 2014, pp. 447-460.

JAFARPOUR, Ali Reza, Modernization Representation in the Pahlavi I Era from the Perspective of Karim Khan Zand Street of Shiraz, Unpublished Master's Thesis in Architecture, Shahid Beheshti University of Tehran, 2012.

JAMALI, Ebrahim, Survey and Demarcation of Shiraz, Unpublished Master's Thesis in Urban Planning, Faculty of Arts and Architecture, Shiraz University, 2001. 
KAMELNIA, H.; MAHDAVINEZHAD, M. J., Introduction to Contemporary Architecture from East to West and Examination of the Fundamentals and the Origins of its Formation, Architect Science, Tehran 2012.

KAYANI, Muhammad Yousof, Introduction to Iranian Art of Tiling, Reza Abbasi Museum, Tehran 1983.

KAYANI, Muhammad Yousof, Decorations Related to Iranian Architecture in the Islamic Period, National Islamic Cultural Heritage Organization, Tehran 1997.

KAYANI, Mostafa, Pahlavi I Era Architecture: Transformation of Thoughts, the Emergence, and Formation of the Twenty Years of Iranian Architecture from 1920 to 1941, Institute of Contemporary Iranian History Studies, Tehran 2004.

MAHEROLNAGHSH, Mahmud, Motif Design and Implementation in the Iranian Tile Work in the Islamic Period (the second volume on girih tiling), Vol. 2, Ministry of Culture and Islamic Guidance, Tehran 1983.

MAHEROLNAGHSH, Mahmud, Tile and its Application, Tehran 2002.

MIRINEZHAD, Shoheil, "Romanticism in Contemporary Iranian Architecture (with Emphasis on the Architecture of the Pahlavi II Period after 1962), Fine Arts, 18 (1), 2013, pp. 91-102.

MOJARAD TAKESTANI, Ardeshir, Animal Design in Iranian Book Design Art, Tehran 2013.

MONTAZER, Maryam, Investigating the Effects of the Transition from Tradition to Modernity (Modernism) on the Formation of Shiraz's Residential Architecture and its Adornments, Unpublished Master's Thesis in Art Research, Faculty of Arts and Architecture, Shiraz University, Shiraz, 2014.

MOSTAFAVI, S. Muhammad Taghi, Land of Pars, National Monuments Association, Tehran 1964.

PAKBAZ, Ruiin, Iranian Painting from the Old Times to the Present, Tehran 2008.

PORTER, Venetia, Islamic Tiles, Translator: Shayetefar Manaz, Tehran 2010.

RAJABI, Parviz, Iranian Architecture and the Pahlavi Era, Tehran 1976.

RAZMJOUEI, Behruz, Investigating the Process of Integrating Rural Areas into Urban Centers: Case Study of Shiraz, Unpublished Master's Thesis in Urban Planning, Faculty of Arts and Architecture, Shiraz University, 2005.

SAFFAI, Azar, Investigation of Painting Decorations in Wooden Ceilings of Shiraz Houses During the Qajar Period, Unpublished Master's Thesis in Art Research, Faculty of Arts and Architecture, Shiraz University, 2015.

SHARVEH, A., ANOOSAFAR, M., Glaze, Tile, and Pottery, Tehran 1995.

SOUDAVAR DIBA, Leila, "Flower and Bird Motifs", Month Art Book, 160, 2011, pp. 46-57.

WUlfF, Hans E., The Traditional Crafts of Persia, Cambridge 1966.

YAVARI, H.; HAKKAKBASHI, S., Elements and Decorations of Iranian Architecture, Tehran 2011.

ZEKRI, A.; RANJBAR, H. "The Growth of Shiraz Between 1957 to 2001 Using Remote Sensing and Geographic Information System," Proceedings of the Scientific and Specialized Projects of Urban Development and Architecture of the Provinces of the Country, Center for Study and Research on Urbanization and Architecture, Tehran 2005, pp. 120-148.

ZOMORSHIRIDI, Hosein, Iran's Tiling, Ministry of Housing and Urban Development, Tehran. www.reza-mohammadian.ir, september 19th 2013. 